\title{
Medicinal Plants and Their Traditional Uses in Ramkot Village, Kathmandu Nepal
}

\begin{abstract}
This study aimed to document the traditional medicinal knowledge of local people of Ramkot village about plants to cure various diseases. Primary data were collected from old aged people of village by using semi structured interview of Key informants. A total of 51 medicinal plants belonging to 38 families and 51 genera were documented to treat different diseases and injuries. The highest (29) number of medicinal plants were herbs and lowest (2) were climbers. Majority of them were used to treat gastrointestinal disorders. The study area was found to be rich in plant resources and the old aged people have ample knowledge on the use of medicinal plants. But young generation is not interested about herbal medicine due to easy access of hospitals and modern medical facilities. Due to lack of proper documentation, conservation and cultivation practices, many useful plant species are at risk of extinction in this village.
\end{abstract}

Key words: Diseases, Herbs, medicinal plants, conservation

\section{Introduction}

Plants have been used for human benefit from the time immemorial (Summer,2000). Traditional use of plant and plant resources for medicinal purpose has long history in Nepal. The use of medicinal plants in Nepal is as old as human civilization. The earliest evidence of use of plants as medicine is found in Rigveda written between 4500 and 1600 BC (Anonymous, 1970). The rural communities of Nepal heavily depend on the plant diversity for the fulfillment of their basic needs and utilize them according to their traditional knowledge and practice (Joshi et al, 2011). Plants having medicinal use are collected from various habitats. At present, most of these habitats with useful species are under threat due to habitat destruction, unsustainable harvesting and over exploitation (Chaudhary, 1998). It has been reported that medicinal plants are responsible for maintaining the health of $70-80 \%$ population of Nepal (Manandhar, 2002). Pandey (1961) for the first time reported 73 medicinal and aromatic plants (MAPs) in Nepal. Manandhar (2002) reported more than 900 species of medicinal plants in Nepal. According to MoAD, 2017 rural people in Nepal use at least 1, 463 species of herbal medicines. Shrestha et al (2002) reported 1614 species, Baral and Kurmi (2006) reported1792 species, Ghimire et al (2008) reported a total of 1950 species and Rokaya et al (2012) reported 1792 to 2331 plant species as potential medicinal and aromatic plants in Nepal.Various researchers have conducted the research to document the ethnomedical knowledge of different communities in Nepal.Acharya and Acharya (2009) documented 45 different plant species belonging to 31 families and 42 genera in 
Parroha VDC in Rupandehi district. Majority of them were found as tree treating gastrointestinal disorders, fever, cuts and wounds etc. Joshi et al. (2011) found 87 plant species belonging to 54 families in Machhegaun, Kathmandu Nepal. Majority of them were herb and Asteraceae family was found most frequent. Joshi et al. (2018) documented 44 medicinal plants belonging to 29 families in Chitwan district. Most of them were used for gastrointestinal disorders. Singh et al. (2018) found that the females have better therapeutic knowledge than males because most of the year male members moved away for their livelihood and females deal common ailments at home. Mall et al. (2015) found 132 ethnomedicinal plant species belonging to 99 genera and 67 families in Parbat district of Western Nepal. Higher number of plants species were used for gastrointestinal problems. Luitel et al. (2014) found 161 ethnomedicinal plant species belonging to 86 families and 144 genera used by Tamang community in Makwanpur district, central Nepal. Majority of them were herbs treating gastrointestinal diseases followed by cuts and wounds. Adhikari et al. (2019) found 105 medicinal plants belonging to 58 families and 99 genera. The highest number of plants was used for gastrointestinal disorders. Acharya (2012) found 161 ethnomedicinal plant species belonging to 87 families and 144 genera. Majority of them were herb.

Ramkot lies in Nagarjun Municipality about $7 \mathrm{Km}$ west from the heart of Kathmandu. It is boardered by Suychatar, Ichanghu, Sitapaila and Bhimdhunga villages. Formerly it was Ramkot VDC of Kathmandu district. According to 1991 census the population of Ramkot village is 5327 and the total household is 972 . Ramkot is inhabited by various ehnic groups like Newar, Sanyasi, Bramhin, Chhetri, Tamang and Muslims. Druk Amitabh mountain with biggest Buddha stupa all over Nepal is one of its centre of attraction. Ramkot was name to signify that Lord Ram was here during his exile. According to legends defines the Lord Ram built a building to keep his weapons. This study is designed to document the medicinal plants in the Ramkot village. It also aims to document the traditional knowledge regarding the medicinal plants found in this village.

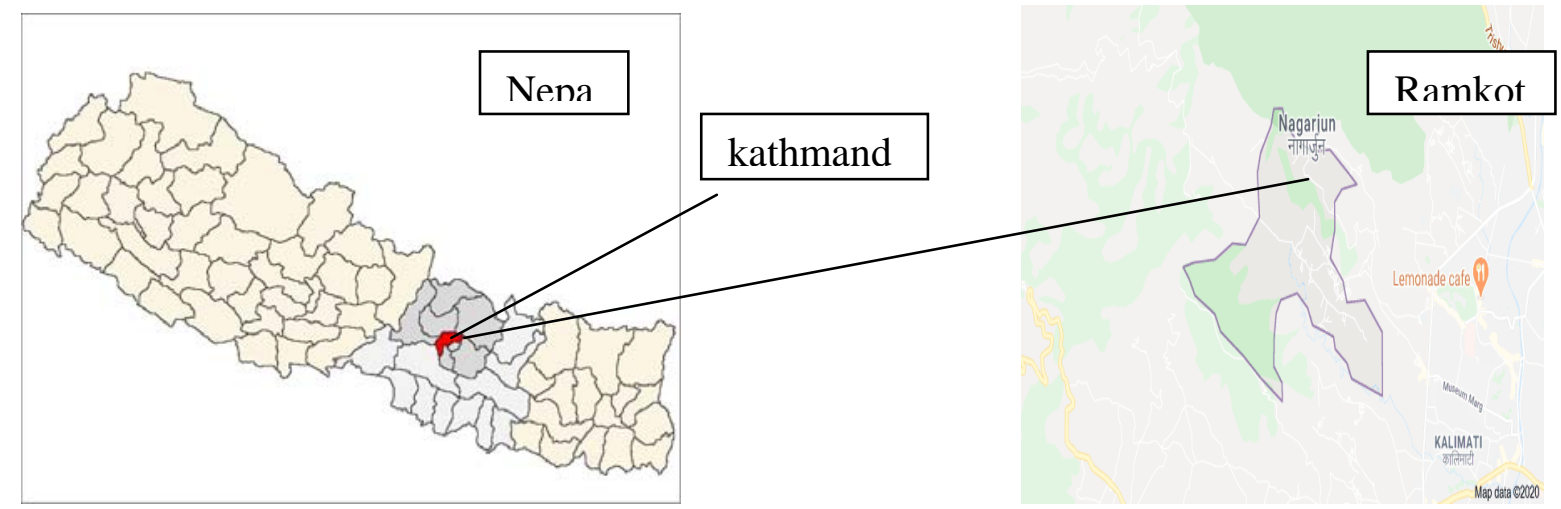

Source: www.google map.com.np 


\section{Materials and methods}

The primary data were obtained duringfield visitsand interview with the 25 key informantsof age 50 and above. The secondary data were obtained from Nagarjun municipality office, Ramkot ward office, and different literatures, national and international journals. Field visit was carried out during june-July 2019. The plant materials were identified with the help of experts and herbarium specimens deposited in Botany department, Patan Multiple Campus. The collected data were tabulated and analysed with the help of Microsoft Excel 2010.

\section{Results and Discussions}

The study documented a total of 51 species of commonly used medicinal plants in the area which was represented by 38 families and 51 general (Table 1). The majority species were herbs (29 species), followed by shrubs (12 species), trees ( 8 species) and climbers (2 species) (Figure 1). The families with the highest number of species were Asteraceae (5 species) and Amaranthaceae (3 species). The families Bereridaceae, Apiaceae, Poaceae, Solanaceae, Urticaceae, Ericaceae, Lamiaceae and Araceae were represented by two species each while remaining 27 families constitutes single species only (Figure 2). The highest numbers of plants were used for gastro intestinal disorder (12 species) followed by cuts and wounds (9 species) and fever ( 6 species) (Figure 3). In terms of plant parts use, Whole parts, underground parts, leaves, twigs and barks were in top priorities (Figure 4). Most of the documented medicinal parts were Angiosperm (55 species dicots \& 5 species monocots) and one species Pteridophytes. The study shows more or less similar results with Acharya and Acharya, 2009 (Tharu community, Rupandehi district), Acharya, 2012 (Magar community, Gulmi district), Adhikari et al., 2019 (Machhapuchhre Rural Municipality, Kaski district), Luitel et al., 2014 (Tamang community, Makwanpur district).Joshi et al. 2018 (Chitwan district), Joshi et al., 2011 (Machhegaoun village, Kathmandu) and Shrestha et al., 2016 (Eastern Nepal). 
Patan Pragya (Volume: 6, Number: 1 2020)

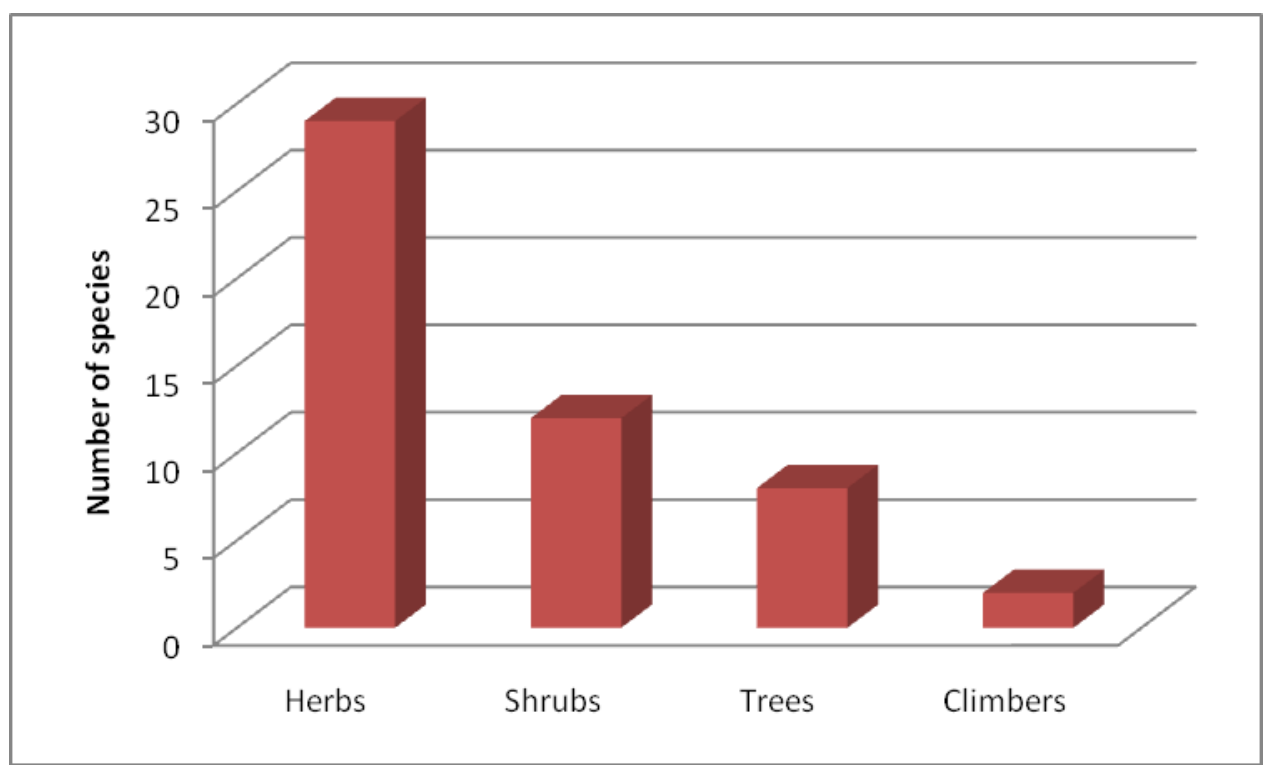

Figure 1. Habits of plants

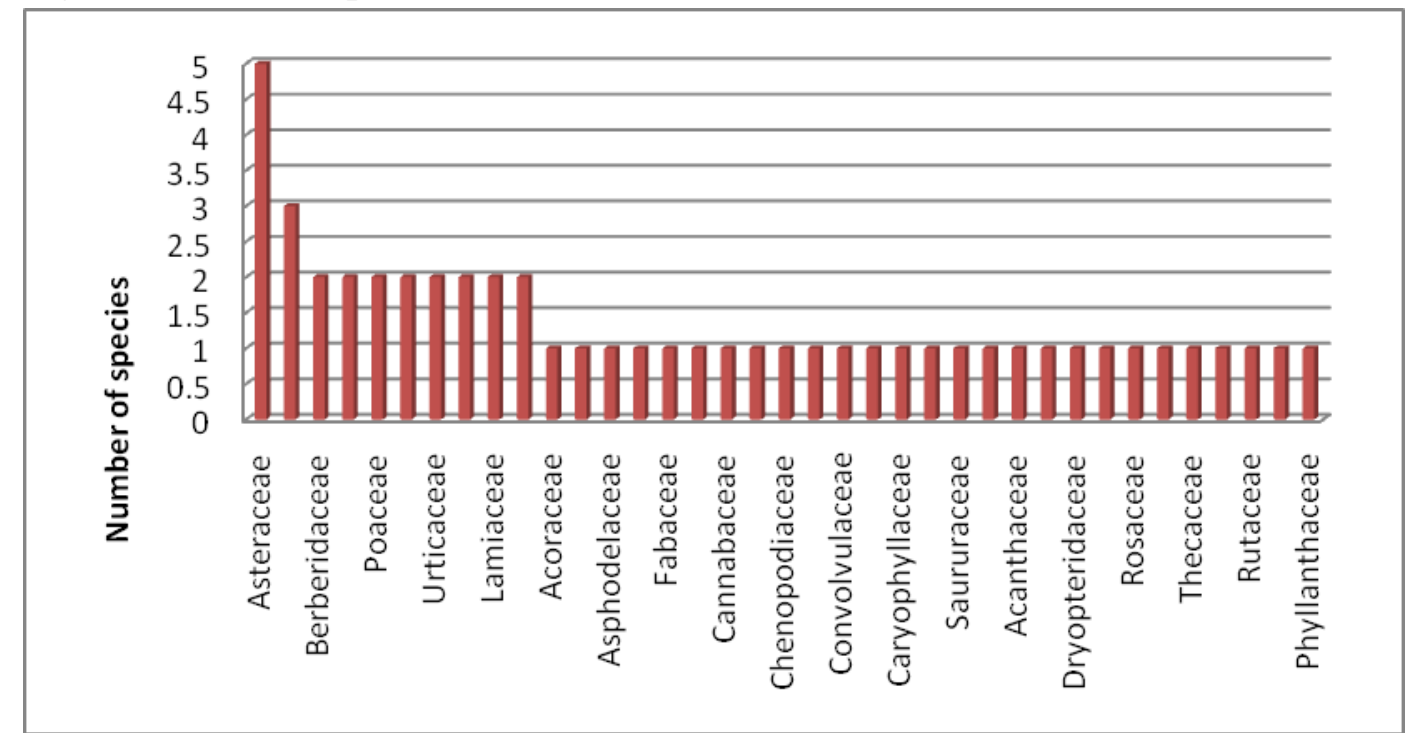

Figure 2. family wise distribution of plant species

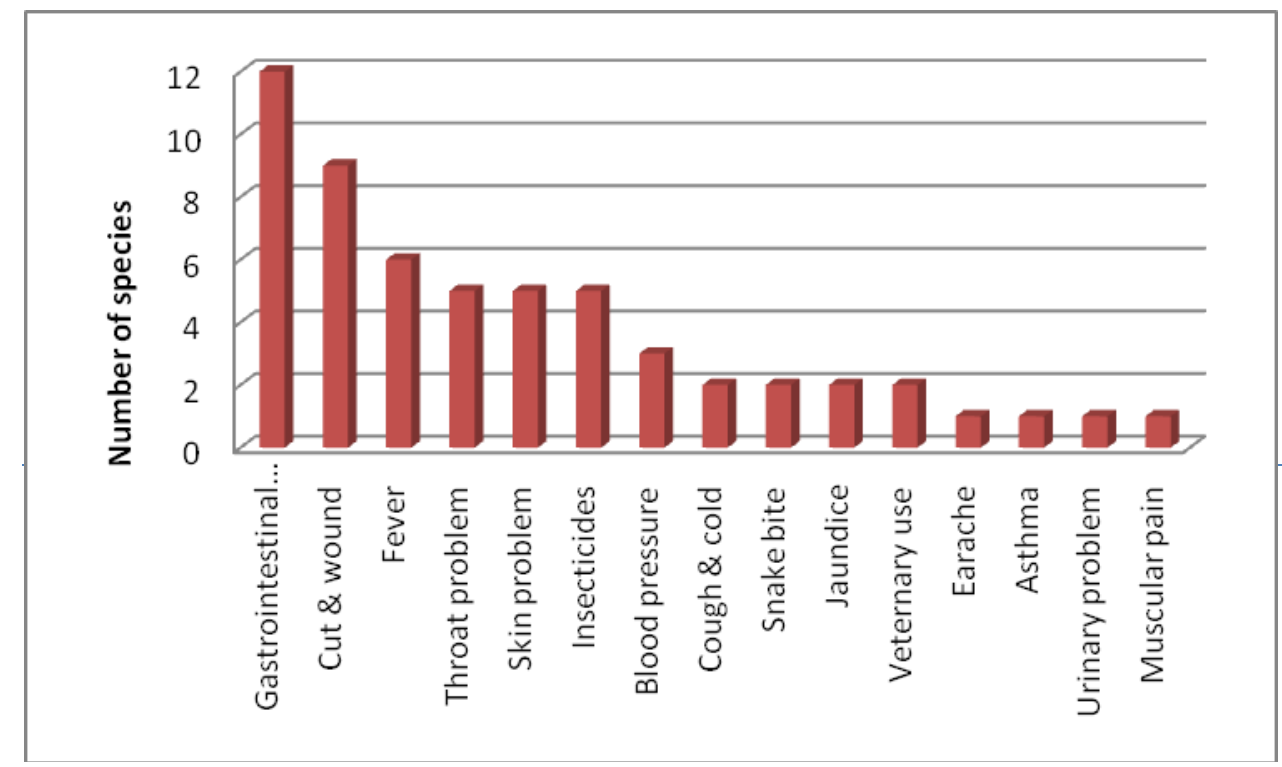


Figure 3. Plants used in various health problems

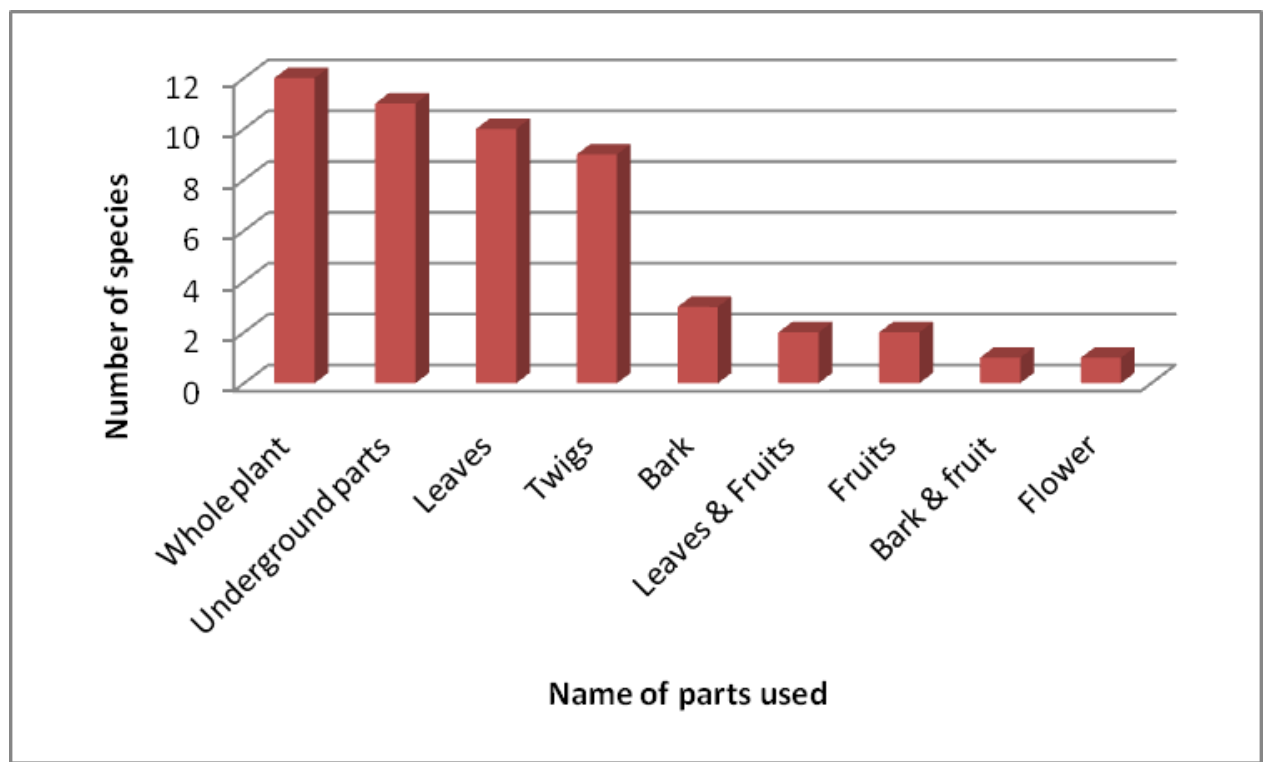

Figure 4. Parts used in the treatment of various health problems

Table 1. List of medicinal plants documented in Ramkot village area

\begin{tabular}{|l|l|l|l|l|l|}
\hline S.no & Scientific name & Local name & Family & Habit & Medicinal uses \\
\hline 1 & $\begin{array}{l}\text { Achyranthus } \\
\text { bidentata Blume }\end{array}$ & Datiwan & Amaranthaceae & Herb & $\begin{array}{l}\text { Leaf juice is } \\
\text { used for typhoid } \\
\text { stem is used in } \\
\text { toothache. }\end{array}$ \\
\hline 2 & Acorus calamus L. & Bojho & Acoraceae & Herb & $\begin{array}{l}\text { Rhizome is } \\
\text { chewed to cure } \\
\text { throat problems. }\end{array}$ \\
\hline 3 & $\begin{array}{l}\text { Ageratina } \\
\text { adenophora (Spreng.) } \\
\text { R,M.King \& H.Rob. }\end{array}$ & Kalmunte & Asteraceae & Herb & $\begin{array}{l}\text { Leaf and twig } \\
\text { juice is used in } \\
\text { cuts and wound } \\
\text { to stop bleeding. }\end{array}$ \\
\hline 4 & $\begin{array}{l}\text { Ageratum conyzoides } \\
\text { L. }\end{array}$ & Gandhe & Asteraceae & Herb & $\begin{array}{l}\text { Plant juice is } \\
\text { applied in cuts to } \\
\text { stop bleeding. }\end{array}$ \\
\hline 5 & $\begin{array}{l}\text { Allium } \text { wallichii } \\
\text { Kunth }\end{array}$ & Dundu & Alliaceae & Herb & $\begin{array}{l}\text { Bulbs are } \\
\text { chewed to treat } \\
\text { cough and colds. }\end{array}$ \\
\hline 6 & $\begin{array}{l}\text { Aloe vera (L.) } \\
\text { Burman fil. }\end{array}$ & Gheu kumara & Asphodelaceae & Herb & $\begin{array}{l}\text { Leaf is used to } \\
\text { cure burn and } \\
\text { skin irritation. } \\
\text { Leaf juice is }\end{array}$ \\
\hline
\end{tabular}


Patan Pragya (Volume: 6, Number: 1 2020)

\begin{tabular}{|c|c|c|c|c|c|}
\hline & & & & & $\begin{array}{l}\text { taken to lower } \\
\text { blood pressure. }\end{array}$ \\
\hline 7 & $\begin{array}{l}\text { Alternanthera sessilis } \\
\text { (L.) R.Br }\end{array}$ & & Amaranthaceae & Herb & $\begin{array}{l}\text { Leaf juices and } \\
\text { paste is used in } \\
\text { bleeding, cuts } \\
\text { and wounds. }\end{array}$ \\
\hline 8 & $\begin{array}{l}\text { Amaranthus viridus } \\
\text { L. }\end{array}$ & Latte & Amaranthaceae & Herb & $\begin{array}{l}\text { Vegetables and } \\
\text { pickles of young } \\
\text { twigs are useful } \\
\text { to treat } \\
\text { constipation. }\end{array}$ \\
\hline 9 & $\begin{array}{l}\text { Arisaema tortuosum } \\
\text { (Wallich) Schott }\end{array}$ & $\begin{array}{l}\text { Sarpako } \\
\text { makai, Banko }\end{array}$ & Araceae & Herb & $\begin{array}{l}\text { Corm paste is } \\
\text { applied in snake } \\
\text { bite. }\end{array}$ \\
\hline 10 & $\begin{array}{l}\text { Artemesia indica } \\
\text { Willdenow }\end{array}$ & Titepati & Asteraceae & Herb & $\begin{array}{l}\text { Leaves and twigs } \\
\text { are used as } \\
\text { insecticides. } \\
\text { Dried leaves are } \\
\text { burned to repel } \\
\text { mosquitoes. }\end{array}$ \\
\hline 11 & $\begin{array}{l}\text { Asparagus raceosus } \\
\text { Willdenow }\end{array}$ & Kurilo & Asparagaceae & Shrub & $\begin{array}{l}\text { Young twigs are } \\
\text { cooked and } \\
\text { taken as tonic. }\end{array}$ \\
\hline 12 & Bauhinia variegate L. & Koiralo & Fabaceae & Tree & $\begin{array}{l}\text { Bark decoction } \\
\text { is used in gastric. }\end{array}$ \\
\hline 13 & $\begin{array}{l}\text { Berberis asiatica } \\
\text { Roxb.ex de Candolle }\end{array}$ & Chutro & Berberidaceae & Shrub & $\begin{array}{l}\text { The root extract } \\
\text { is given to cure } \\
\text { jaundice. }\end{array}$ \\
\hline 14 & $\begin{array}{l}\text { Buddleja asiatica } \\
\text { Loureiro }\end{array}$ & Bhimsenpati & Buddlejaceae & Tree & $\begin{array}{l}\text { Leaf juice is } \\
\text { used to cure skin } \\
\text { diseases. }\end{array}$ \\
\hline 15 & Cannabis sativa L. & Bhang, Ganja & Cannabaceae & Shrub & $\begin{array}{l}\text { Fresh twigs are } \\
\text { given to cattle to } \\
\text { treat diarrhoea. }\end{array}$ \\
\hline 16 & Celtis australis L. & Khari & Ulmaceae & Tree & $\begin{array}{l}\text { The paste of } \\
\text { plant is used to } \\
\text { cure muscular } \\
\text { pain. }\end{array}$ \\
\hline 17 & Centella asiatica L. & Ghodtapre & Apiaceae & Herb & $\begin{array}{l}\text { Plant juice is } \\
\text { used to treat } \\
\text { jaundice and } \\
\text { high blood } \\
\text { pressure. }\end{array}$ \\
\hline 18 & $\begin{array}{l}\text { Chenopodium album } \\
\text { L. }\end{array}$ & Bethe & Chenopodiaceae & Herb & $\begin{array}{l}\text { Vegetables and } \\
\text { pickles are made } \\
\text { and taken as }\end{array}$ \\
\hline
\end{tabular}


Patan Pragya (Volume: 6, Number: 1 2020)

\begin{tabular}{|c|c|c|c|c|c|}
\hline & & & & & anthelmintic. \\
\hline 19 & $\begin{array}{l}\text { Colacasia esculenta } \\
\text { (L.) Schott }\end{array}$ & Karkalo & Araceae & Herb & $\begin{array}{l}\text { Vegetable is } \\
\text { useful in } \\
\text { constipation. }\end{array}$ \\
\hline 20 & $\begin{array}{l}\text { Cirsium verutum } \\
\text { (D.Don) Sprengel }\end{array}$ & Thakal & Asteraceae & Herb & $\begin{array}{l}\text { Fresh root and } \\
\text { young shoot is } \\
\text { chewed in throat } \\
\text { pain. }\end{array}$ \\
\hline 21 & $\begin{array}{l}\text { Cissampelos pareira } \\
\text { L. }\end{array}$ & Batulo paat & Menispermaceae & Climber & $\begin{array}{l}\text { Tuber is crushed } \\
\text { and paste is } \\
\text { given increase } \\
\text { milk production } \\
\text { of domestic } \\
\text { animals. }\end{array}$ \\
\hline 22 & $\begin{array}{l}\text { Cuscuta reflexa } \\
\text { Roxb. }\end{array}$ & Aakash beli & Convolvulaceae & Climber & $\begin{array}{l}\text { Plant juice is } \\
\text { used in jaundice } \\
\text { and high blood } \\
\text { pressure. }\end{array}$ \\
\hline 23 & $\begin{array}{l}\text { Cynodon dactylon } \\
\text { (L.) Persoon }\end{array}$ & Dubo & Poaceae & Herb & $\begin{array}{l}\text { Plant juice is } \\
\text { used in burning } \\
\text { sensation, cuts } \\
\text { and wounds. }\end{array}$ \\
\hline 24 & $\begin{array}{l}\text { Cynoglossum } \\
\text { zeylanicum Thung. }\end{array}$ & Kanike kuro & Boraginaceae & Herb & $\begin{array}{l}\text { Leaf juice is } \\
\text { used to control } \\
\text { bleeding in cuts } \\
\text { and wounds. }\end{array}$ \\
\hline 25 & $\begin{array}{l}\text { Datura stramomium } \\
\text { L. }\end{array}$ & Dhaturo & Solanaceae & Shrub & $\begin{array}{l}\text { Grinded seeds } \\
\text { mixed with } \\
\text { honey are used } \\
\text { treat asthma. } \\
\text { Leaf juice is } \\
\text { dropped in ear to } \\
\text { treat earache. }\end{array}$ \\
\hline 26 & $\begin{array}{l}\text { Drymaria villosai } \\
\text { Chamisso \& Schl. }\end{array}$ & Abijalo & Caryophyllaceae & Herb & $\begin{array}{l}\text { Plant juice is } \\
\text { used in urine } \\
\text { infection. }\end{array}$ \\
\hline 27 & Eclipta prostrata L. & Bhringaraj & Asteraceae & Herb & $\begin{array}{l}\text { Plant paste is } \\
\text { used in cuts and } \\
\text { wounds. }\end{array}$ \\
\hline 28 & Ficus reliogosa L. & Pipal & Moraceae & Tree & $\begin{array}{l}\text { Bark juice is } \\
\text { used to treat } \\
\text { dysentery, } \\
\text { diarrhea and is } \\
\text { also useful in } \\
\text { snakebite. }\end{array}$ \\
\hline
\end{tabular}


Patan Pragya (Volume: 6, Number: 1 2020)

\begin{tabular}{|c|c|c|c|c|c|}
\hline 29 & $\begin{array}{l}\text { Gonostegia hirta } \\
\text { (Blume) Miq. }\end{array}$ & Maslahari & Urtticaceae & Herb & $\begin{array}{l}\text { The plant paste } \\
\text { is applied in } \\
\text { muscle crack. }\end{array}$ \\
\hline 30 & $\begin{array}{l}\text { Houttuynia chordate } \\
\text { Thunberg }\end{array}$ & Gandhe jhar & Saururaceae & Herb & $\begin{array}{l}\text { Pickles of whole } \\
\text { plant are given to } \\
\text { relief from body } \\
\text { pain. }\end{array}$ \\
\hline 31 & $\begin{array}{l}\text { Hydrocotyl } \\
\text { sybthorpoides Lam. }\end{array}$ & $\begin{array}{l}\text { Sano } \\
\text { ghodtapre }\end{array}$ & Apiaceae & Herb & $\begin{array}{l}\text { Plant juice is to } \\
\text { treat fever. The } \\
\text { plant paste is } \\
\text { applied in cuts } \\
\text { and wounds. }\end{array}$ \\
\hline 32 & Jasminum humile L. & Sano jai & Oleaceae & Shrub & $\begin{array}{l}\text { Leaves juice is } \\
\text { given to treat } \\
\text { fever. Fresh } \\
\text { leaves are } \\
\text { chewed to treat } \\
\text { sore throat and } \\
\text { tonsil. }\end{array}$ \\
\hline 33 & Justicia adhatoda L. & Asuro & Acanthaceae & Shrub & $\begin{array}{l}\text { Leaf juice is } \\
\text { used to cure } \\
\text { malaria, } \\
\text { bronchitis and } \\
\text { cough. }\end{array}$ \\
\hline 34 & $\begin{array}{l}\text { Lindera neesiana } \\
\text { Kurz }\end{array}$ & Siltimur & Lauraceae & Shrub & $\begin{array}{l}\text { Seeds are taken } \\
\text { with salt and } \\
\text { turmeric powder } \\
\text { to cure gastritis. }\end{array}$ \\
\hline 35 & $\begin{array}{l}\text { Lyonia ovalifolia } \\
\text { (Wallich) Drude }\end{array}$ & Seto aangeri & Ericaceae & tree & $\begin{array}{l}\text { Bark paste is } \\
\text { used to treat } \\
\text { scabies. }\end{array}$ \\
\hline 36 & $\begin{array}{l}\text { Mahonia } \\
\text { nepaulensisde } \\
\text { Candolle }\end{array}$ & $\begin{array}{l}\text { Jamane } \\
\text { mandro }\end{array}$ & Berberidaceae & Shrub & $\begin{array}{l}\text { Leaf juice is } \\
\text { useful in mouth } \\
\text { ulcer and tonsil. }\end{array}$ \\
\hline 37 & Mentha spicata L. & Bawari & Lamiaceae & Shrub & $\begin{array}{l}\text { Leaf juice is } \\
\text { useful in } \\
\text { dysentery and } \\
\text { gastritis. }\end{array}$ \\
\hline 38 & $\begin{array}{l}\text { Nephrolepis } \\
\text { cordifolia (L.) K. } \\
\text { presl }\end{array}$ & Pani amala & Dryopteridaceae & Herb & $\begin{array}{l}\text { Tuber juice is } \\
\text { useful in } \\
\text { dehydration. }\end{array}$ \\
\hline 39 & $\begin{array}{l}\text { Ocmimum } \\
\text { tenuiflorum } \mathrm{L} .\end{array}$ & Tulsi & Lamiaceae & Herb & $\begin{array}{l}\text { Leaf juice is } \\
\text { used in cold and } \\
\text { cough. It also } \\
\text { used to cure skin } \\
\text { diseases. }\end{array}$ \\
\hline
\end{tabular}


Patan Pragya (Volume: 6, Number: 1 2020)

\begin{tabular}{|c|c|c|c|c|c|}
\hline 40 & $\begin{array}{l}\text { Phyllanthus emblica } \\
\text { L. }\end{array}$ & Amala & Phyllanthaceae & Tree & $\begin{array}{l}\text { Bark juice is } \\
\text { used in } \\
\text { dysentery, fruit } \\
\text { is tonic and used } \\
\text { in shore throat. }\end{array}$ \\
\hline 41 & $\begin{array}{l}\text { Plantago erosa } \\
\text { Wallich }\end{array}$ & Esapgol & Plantaginaceeae & Herb & $\begin{array}{l}\text { Leaf paste is } \\
\text { used in insect } \\
\text { bites. }\end{array}$ \\
\hline 42 & $\begin{array}{l}\text { Rhododendron } \\
\text { arboretum Sm. }\end{array}$ & Laligurans & Ericaceae & Tree & $\begin{array}{l}\text { Fresh or dry } \\
\text { petals are useful } \\
\text { to treat } \\
\text { dysentery. Dry } \\
\text { petals are } \\
\text { chewed to } \\
\text { extract the fish } \\
\text { bone or wheat } \\
\text { splinter stuck in } \\
\text { throat. }\end{array}$ \\
\hline 43 & Rubus ellipticus Sm. & Ainselu & Rosaceae & Shrub & $\begin{array}{l}\text { Root juice is } \\
\text { given for fever, } \\
\text { diarrhea and } \\
\text { dysentery. }\end{array}$ \\
\hline 44 & $\begin{array}{l}\text { Rumex nepalensis } \\
\text { Spreng. }\end{array}$ & Halhale & Polygonaceae & herb & $\begin{array}{l}\text { Root paste is } \\
\text { used to control } \\
\text { blood in cuts and } \\
\text { wounds. }\end{array}$ \\
\hline 45 & Schima wallichii & Chilaune & Thecaceae & Tree & $\begin{array}{l}\text { Bark paste is } \\
\text { used to control } \\
\text { bleeding from } \\
\text { cuts and wounds. }\end{array}$ \\
\hline 46 & Solanum nigrum L. & Kaligedi & Solanaceae & Herb & $\begin{array}{l}\text { Ripe fruits used } \\
\text { in constipation. }\end{array}$ \\
\hline 47 & $\begin{array}{l}\text { Thysanolaena } \\
\text { latifolia (Roxb.Ex) } \\
\text { Hormen }\end{array}$ & Amriso & Poaceae & Herb & $\begin{array}{l}\text { Root decoction } \\
\text { is taken in oral } \\
\text { form during } \\
\text { fever. }\end{array}$ \\
\hline 48 & Urtica dioica L. & Sisnoo & Urticaceae & Shrub & $\begin{array}{l}\text { The young twigs } \\
\text { are cooked and } \\
\text { taken as good } \\
\text { source of iron. }\end{array}$ \\
\hline 49 & $\begin{array}{l}\text { Valeriana jatamansi } \\
\text { Jones }\end{array}$ & Sugandhawala & Valereianace & Herb & $\begin{array}{l}\text { Plant juice is } \\
\text { used as } \\
\text { insecticidal. }\end{array}$ \\
\hline 50 & $\begin{array}{l}\text { Zanthoxulum } \\
\text { armatum de } \\
\text { Candolle } \\
\end{array}$ & Timur & Rutaceae & Shrub & $\begin{array}{l}\text { Leaves and seeds } \\
\text { are used as } \\
\text { insecticides. Few }\end{array}$ \\
\hline
\end{tabular}




\begin{tabular}{|l|l|l|l|l|l|}
\hline & & & & & $\begin{array}{l}\text { seeds are taken } \\
\text { with warm water } \\
\text { to get relief from } \\
\text { indigestion. }\end{array}$ \\
\hline 51 & $\begin{array}{l}\text { Zingiber officinalae } \\
\text { Roscoe }\end{array}$ & Aduwa & Zingiberaceae & Herb & $\begin{array}{l}\text { Rhizome } \\
\text { decoction is used } \\
\text { in vomiting, } \\
\text { common cold } \\
\text { and } \\
\text { stomachache. }\end{array}$ \\
\hline
\end{tabular}

\section{Conclusion}

The present study shows that the Ramkot village is rich in medicinal plants. The older people of the village have greater knowledge about the locally available medicinal plants and their uses but teenagers show no interest for the use of medicinal plants. The reason behind this is easy availability of allopathic medicines. The practice of using medicinal plants is decreasing day by day as consequences the traditional knowledge about the use of medicinal plants is going to be extinct along with older generation. So emphasis should be given and documentation should be done to preserve the traditional knowledge before they have been lost.

\section{References}

Acharya, R. (2012). Ethnobotanical study of medicinal plants of Resunga Hill used by Magar community of Badagaun VDC, Gulmi district, Nepal. Scientific world. 10(10): 54-65.

Acharya, R and Acharya, KP. (2009). Ethnobotanical study of medicinal plants used by the Tharu community of Parroha VDC, Rupandehi district, Nepal. Scientific World.7(7): 80-84.

Adhikari, M. Thapa, R, Kunwar, RM., Devkota, HP. And Poudel, P. (2019). Ethnomedicinal uses of plant resourcesin the Machhapuchhre Rural Municipality of Kaski, Nepal. Medicines. 6(69). Doi: 10.3390/medicines6020069.

Anonymous, 1970. Medicinal plants of Nepal. Department of Medicinal Plants, Kathmandu, Nepal.

Baral, S.R., and Kurmi, P.P. (2006). A compendium of medicinal plants in Nepal., pp. 450451. Pub.: MrsRachana Sharma, MaijuBahal, Chabhil, Kathmandu, Nepal.

Chaudhary, RP.,(1998). Biodiversity in Nepal (Status and Conservation) S. Devi, Saharanpur (U.P). India and Tec Press Books, Bangkok, Thailand.

Ghimire, S., Sapkota, I., Oli, B., and Parajuli, R. (2008). Nontimber forest products of Nepal Himalaya: Database of some important species found in the mountain protected areas andsurrounding regions. Kathmandu: WWF Nepal. 
Joshi, A., Kalauni, D. and Bhattarai, S. (2018). Survey on usage of medicinal plants: A case from Chitwan district of Nepal. SAARC. J.Agri 16(2): 129-241. Doi:10.3329/sja.vl6i2.40265.

Joshi, K., Joshi, R. and joshi, AR. (2011). Indigenous knowledge and uses of medicinal plants in Machhegaoun, Nepal. Indian Journal of Traditional Knowledge.10(2): 281286.

Luitel, DR., Rokaya, MB. And Munzbergova, Z. (2014). Medicinal plants used by Tamang community in the Makawanpur district of central Nepal. Journal of Ethnobiology and Ethnomedicine. 10(5).

Malla, B., gauchan, DP. And Chhetri, RB. (2015). An ethnobotanical study of medicinal plants used by ethnic people in Parbat district of Western Nepal. Journal of Ethnopharmacology.(2015)

Manandhar, NP. (2002). Plants and People of Nepal. Oregon, USA: Timber Press Portland.

MoAD. (2017). The state of Nepal's Biodiversity for Food and Agriculture, Kathmandu: Ministry of Agriculture and Development.

Pandey, P. (1961). Distribution of medicinal plants of Nepal. Symposium on Medicinal Plants, 15-61. Ceylon, India.

Rokaya, M.B., Münzbergová, Z., Shrestha, M.R., and Timsina, B. (2012). Distribution

Patterns of Medicinal Plants along an Elevational Gradient in Central Himalaya, Nepal.

Journal of Mountain Science, 201-213.

Shrestha, K.K., Tiwari, N.N., and Ghimire, S.K. (2002). Medicinal and aromatic plants

database of Nepal. In: Watanabe T, Takano A, Bista MS, Saiju HK (eds.), Proceeding of Nepal-Japan Joint Symposium on Conservation and Utilization of Himalayan Medicinal Plant Resources.

Shrestha, N., Shrestha, S., Koju, L., Shrestha, KK. And Wang, Z. (2016). Medicinal plant diversity and traditional healing practices in Eastern Nepal. Journal of Etnopharmacology.196(2016): 292-301. Doi:10.1016/jep.2016.07.067.

Singh, AG., kumar, A., Tiwari, DD., and Bharati, KV. (2018). New ethnomedicinalclaims from Magar community of Palpa district, Nepal. Indian Journal of Traditional Knowledge. 17(3): 499-511.

Summer, J. (2000). The Natural History of Medicinal Plants. I ${ }^{\text {st }}$ edition. Portland, Oregon, USA, Timber Press. 